\title{
Tomás Carrasquilla, clásico antioqueño
}

$\mathrm{H}$

AY en el occidente de Colombia, entre los ríos Cauca y Magdalena, una extensa región montañosa, de picos escuetos y ásperas cuchillas, de hermosas vertientes y mesetas, y de climas que varian entre el frío de los montes nevados y el ardiente de los llanos tropicales. Esta región es interesante, más que por sus muchos accidentes geográficos, por las gentes que la ocupan, y que, en lucha constante con la naturaleza, avanzan, confiadas y orgullosas, hacia un brillante porvenir de poder y de grandeza.

Descubierta y conquistada por los españoles, a fines del siglo xvi, la región fue luego colonizada por unas dos mil familias asturianas, vizcaínas, castellanas, catalanas y aragonesas, y por unas cuantas de origen morisco y hebreo-español, procedentes de las provincias de Huelva y de Sevilla. Tan pocos colonos vinieron a la remota región atraídos por los ricos minerales de oro que ocultaba en sus ríos y quebradas, en sus vertientes y en las tumbas de sus primitivos moradores; y sus descendientes, aislados durante dos siglos y medio, conservaron muy puras su lengua y sus creencias religiosas; se mezclaron entre sí, y en parte con los indios aborígenes y con los negros africanos traídos para el laboreo de las minas, y adoptaron algunos de sus usos y costumbres. A la región le dieron el nombre de Antioquia - no Antioquía, nombre de una antigua ciudad del Asia $\mathrm{Me}$ nor-, y en sus hogares, sedentarios y patriarcales, se fueron multiplicando con asombrosa rapidez, hasta formar un pueblo nuevo y bien definido de gentes enérgicas, inteligentes, laboriosas, amigas de la libertad, muy apegadas a la tradición y respetuosas de la ley y el orden, y amantes de la acción positiva y del progreso: el pueblo antioqueño, democrático, audaz y prometedor. 
Antioquia y su pueblo presentan un fenómeno vital e histórico como no hay otro semejante en la América hispana: en ninguna otra sección del Continente la población ha crecido tanto, por sí y de sí misma, sin el aporte de nuevas inmigraciones europeas, y en ninguna otra se viene desarrollando una cultura propia, libre de excesivas influencias exteriores. Su pueblo tiñe, pero no destiñe: adopta de lo foráneo sólo lo que le conviene, sin perder su casticismo, y se multiplica y expande con ejemplar tenacidad.

El fenómeno parece milagro. Como parte del antiguo Virreinato de la Nueva Granada, la Provincia de Antioquia sustentaba a fines del siglo xviri una escasa población de unas ciento cincuenta mil personas, entre criollos, mestizos y mulatos. A mediados del siglo $\mathrm{xIx}$-bastante asimiladas ya las gentes de color-, el Estado de Antioquia sustentaba ya un núcleo vigoroso y compacto de unas trescientas mil personas, y ahora, sus descendientes constituyen un cuerpo respetable de unos cuatro millones, que se han extendido por todas las vertientes, mesetas y valles de la Vieja Antioquia, por otras regiones de Colombia, y por los países vecinos, el Ecuador, Venezuela y Centroamérica... Hacia I870, la capital del Estado antioqueño era la Villa de la Candelaria de Medellín, un poblachón cerrado, rutinario y levítico de unos quince mil habitantes. Hoy Medellín, capital del Departamento de Antioquia, es una ciudad progresista y moder. na de más de quinientos mil habitantes, la más hermosa entre las ciudades importantes y florecientes de Colombia. Entre éstas, son antioqueñas también Manizales, Armenia y Pereira -en el Departamento de Caldas-, y las que no lo son del todo -Bogotá, Cali y Barranquilla-, a los antioqueños deben en gran parte su crecimiento y sus adelantos sorprendentes.

Lo que sucede con la población sucede asimismo con el comercio y la industria antioqueños: tanto se han desarrollado, que ya dominan los de la nación y avanzan hacia el exterior...

El pueblo antioqueño posee hondo y firme sentido histórico: se apoya en un pasado de lucha sostenida y victoriosa, y vislumbra su porvenir. Como el castellano en España, el antioqueño parece destinado a orientar, organizar y dirigir la vida y la economía de Colombia y otros países vecinos, menos enérgicos, emprendedores y tenaces.

Durante los siglos Xvi y xvin, el pueblo antioqueño apenas si se hacía notar entre los muchos que señoreaban los reyes de las Españas. Se hallaba en formación, vivía aislado casi por entero, y dedicaba sus pocas energías sólo al comercio en pequeño, a la artesanía, la agricultura del maíz y la ganadería, muy incipientes y locales, y a la minería del oro, cuyos productos -descontados los quintos que se le pagaban al rey extranjero-, 
se transformaban a menudo en joyas familiares $y$ aun en "tesoros" de enterrar... Al estallar la Guerra de la Independencia (I8Io-24), ese pueblo se hizo sentir en el Virreinato y fuera de él, ora por la acción de sus guerreros, ora por la orientación nacionalista de sus ideólogos y legisladores. Ganada la independencia de España, volvió a encerrarse en la Montaña por evitar la anarquía, acendrar ideales y aspiraciones y templar la voluntad para la acción individual y colectiva, y luego, como un río impetuoso en tiempos de lluvia, se salió de madre, sin que nada lo pudiese contener: conquistó los llanos y los montes de la Vieja Antioquia; colonizó los del Sur, creando el nuevo Departamento de Caldas; descendió a los llanos del Tolima y al Valle del Cauca; buscó oportunidades de lucro en casi todas las ciudades y villas de Colombia; estableció contactos ventajosos con Europa y los Estados Unidos; transformó sus instituciones sociales, especialmente las docentes; mejoró e intensificó las industrias tradicionales, $\mathrm{y}$ ha venido creando muchas nuevas, inclusive las manufactureras, que producen variadísimos artículos; construyó vías de comunicación; organizó sistemas eficaces de comercio y de finanzas; multiplicó sus esfuerzos; acrecentó notablemente su riqueza, y entró en el campo de la cultura científica, artística y literaria.

Hasta mediados del siglo XIX, pocas y no muy variadas fueton las actividades científicas y artísticas del pueblo antioqueño, que ya mucho en ellas se distingue. Consistían las primeras en reflejar las ciencias europeas, y muy especialmente la filología y la jurisprudencia, y se reducían las segundas a la arquitectura religiosa y la ornamentación, a la joyería, la ebanistería y otras artes menores, y al cultivo esporádico del ensayo histórico y político, la poesía lírica y el artículo de costumbres, en el cual sobresalió Juan de Dios Restrepo, a quienes algunos llaman "el Larra colombiano". Precaria era la labor literaria en la Antioquia aislada del siglo XIX, y sin embargo, ella nos dio un gran poeta vernacular, Gregorio Gutiérrez González, y un novelista de primer orden, Tomás Carrasquilla, de quien queremos ocuparnos aquí, al presentar algunos de sus cuentos, dejando para más tarde la empresa de presentar siquiera dos de sus novelas, $\tan$ castizas y antioqueñas como los cuentos.

\section{II}

Tomás Carrasquilla nació en Santodomingo - villorrio "feo, frío y faldudo, encaramado en los riscos de Antioquia"-, el 23 de enero 
de 1858 , y murió en Medellín, el I9 de diciembre de 1940, consagrado ya como el primer novelista de Colombia.

La vida de Carrasquilla carece de interés dramático. Lo que en él interesa son su personalidad y las obras literarias en que logró darle expresión fiel y perdurable.

Carrasquilla fue un hombre afortunado. Pertenecía a una rica familia de montañeses. Era hijo de don Rafael Carrasquilla Isaza y doña Ecilda Naranjo Moreno, hidalgos los dos, chapados a la antigua, conservadores, muy devotos y "más blancos que el Rey de las Españas", como el hijo mimado nos dice en su "Autobiografía". No padeció escaceses ni reveses de ninguna clase, y permaneció siempre soltero, gozando tranquilamente del afecto de sus muchos amigos y allegados.

De niño, "Tomasito" concurrió "a cuantos colegios hay por esas seranías", sin aprender mucho, y de adolescente, cursó dos años de estudios en la Universidad de Antioquia, honra y prez de la Villa de la Candelaria de Medellín, distinguiéndose más por sus travesuras y escapadas que por su aprovechamiento. La revolución del 76 interrumpió su carrera universitaria. Se acogió en Santodomingo al abrigo de su hogar. Ocupó allí el cargo de Secretario del Juzgado Municipal y más tarde el de Juez. De I9I5 a I9I6 desempeñó a disgusto un puesto en el Ministerio Nacional de Obras Públicas de Bogotá, ciudad donde había estado en 1896 , con motivo de la edición de Frutos de mi tierra, su primera novela. Pasó los últimos veinticuatro años de la vida en Medellín, y ya de edad muy avanzada, ciego y tullido, a los amanuenses les dictó la trilogía Hace tiempos, novela que coronó su vasta obra literaria y le ganó el premio nacional Vergara y Vergara de Literatura y Ciencia. Poco antes había recibido la Gran Cruz de Boyacá, en reconocimiento oficial de sus grandes méritos de ciudadano y de escritor.

Los dos viajes a Bogotá fueron los únicos que Carrasquilla hizo fuera de Antioquia. No estuvo en ningún pais extranjero, ni visitó otras comarcas colombianas. La de Antioquia cra su predilecta. Para ella vivió y se expresó, brindándole todas sus.vigilias y afanes de patriota, y todos sus empeños de artista del lenguaje y sus ensueños de poeta reminiscente y esperanzado...

Tomás Carrasquilla, el solterón empedernido, era un hombre afable y simpático, aunque parecía petulante, displicente y mordaz. Yo lo conocí en Bogotá, el año de igi6. Tenía entonces cincuenta y ocho años. Erá alto y fornido, ancho de espaldas, de cabeza relativamente pequeña, y de andar firme y reposado. Gustaba mucho de la conversación. Se reunía con parientes o amigos, en las salas, las esquinas, los portones, y más a 
menudo en tenduchas y cantinas semioscuras donde "el Hermano Anís" aumentaba "todas las potencias" del hombre, haciéndolo vivir "con intensidad que toca en el frenesí". Prefería la "compaña" de artistas y bohemios, y si no bebía demasiado - pues entonces se ponía taciturno-, soltaba "Ia sin hueso" y divertía y escandalizaba a sus contertulios con su charla sabrosa y variada, tejida de consejas picantes y deliciosos apuntes y chascarrillos, y salpicada de frases incisivas e hirientes, de imágenes caseras y de "palabras escatológicas, que prodigaba con ingenua intemperancia", según dijo el poeta Eduardo Castillo, uno de sus contertulios y admiradores bogotanos. Al conversar resultaba temible y encantador: ponía en juego las manos, marfilinas y nerviosas, los ojos oscuros, chiquitos y vivarachos, los labios medio hundidos y el bigote un tanto hirsuto que, bajo la aguileña nariz, contraste hacía con su calva y sus mejillas, tan sontosadas, y con la frente, muy alta y abombada. Y si estaba de vena, hablaba de todo; de política, de historia, de filosofía, de literatura..., y todo lo desmenuzaba con entera libertad, no como un hombre resentido a quien corroen la envidia y los recelos, sino como un espíritu vigoroso, sincero e insobornable, enemigo de lisonjas, mentiras y simulaciones. Sentia el delicioso placer de "descuerar" a sus rivales, y el muy sutil de deslucir a sus amigos, y sin embargo, era liberal, generoso y compasivo con unos y con otros...

Inclinado por naturaleza a ciertos pecados capitales, como la pereza y la intemperancia, a quienes rendía "culto ardiente", según su propia confesión, Carrasquilla nunca pudo hacer en la vida "nada de formalidad". Se la pasaba leyendo, conversando y buscando materiales para sus cuadros, cuentos y novelas, inspirados casi todos en la naturaleza, la historia, el pueblo, las costumbres y las tradiciones de Antioquia, que amaba con ternuras de hijo bueno, y que interpretaba con simpatía de artista discreto y orgulloso.

Carrasquilla se documentaba bien. En Santodomingo se dio de joven al "dulce vicio de la lectura", en parte por disposición natural, en parte por librarse del tedio parroquiano. Allá leyó "de cuanto hay, bueno y malo, sagrado y profano, lícito y prohibido, sin método, sin plan ni objetivo determinado". ¿Qué autores leería? Êl no lo dice en ninguno de sus escritos, y sí declara que no tuvo "predilectos". Sólo de paso nombra a algunos, y sin embargo, fácil resulta señalar a los novelistas y poetas castellanos a quienes debió leer y estudiar, allá en ese villorrio adormecido donde tenía amigos tan íntimos como Francisco de Paula Rendón, su coterráneo y condiscípulo, cultor de las letras como él, y novelista vernacular y castizo de singulares prendas. 
¿Qué autores leería?

En primer lugar, el joven Carrasquilla, por necesidad de los tiempos y del medio ambiente, leería a los autores castellanos más conocidos entonces en su tierra, vale decir, a los románticos de España y de Colombia, y muy especialmente a Zorrilla y el Duque de Rivas, por su afición a las leyendas patrias; a Mesonero Romanos y Larra, por su vena satírica y burlona; a Gregorio Gutiérrez González, por su antioqueñismo poético; a Juan de Dios Restrepo ("Emiro Kastos"), costumbrista libre y mordaz, y al "Indio" Juan de Dios Uribe, antioqueño también, y panfletista de gran mérito, a quien admiraba sin reservas. En segundo lugar, leería con asiduidad a los clásicos españoles, sobre todos a Cervantes, Quevedo y Fernando de Rojas, los favoritos de siempre entre los hidalgos e intelectuales de Antioquia. Y en tercer lugar, lecría con cuidado a Trueba y a Fernán Caballero, restauradores del realismo español, a los maestros Alarcón, Valera, Palacio Valdés, "Clarín" y Coloma, y más a la Pardo Bazán, Blasco Ibáñez y Galdós, a quienes consideraba supremos en el arte de novelar en castellano. A Pereda lo vino a leer más tarde, como leyó a los naturalistas franceses e ingleses, a los simbolistas y los decadentes, y a los maestros rusos, con quienes simpatizaba por lo fieles a su tierra y a su pueblo.

El joven Carrasquilla leía mucho, y analizaba lo leído, confrontando unos autores con otros, con esa independencia de criterio que tanto lo distinguió: a los costumbristas típicos - tan "amenos", según la crítica oficial-, los hallaba sosos, superficiales y decorativos, sin exceptuar ni al colombiano Eugenio Díaz, cuya novela Manuela ( 1866) - "la más acabada de cuantas se han escrito en América", como creyó entonces Cejador y Frauca-, le parecía imperfecta, por "no ser estudio de caracteres", y a pesar del "hermoso realismo" que despliega en la descripción de las costumbres; a los románticos, con la excepción de Gutiérrez González, los hallaba insufribles, por su sensiblería, su pesimismo, su simulación y su amanerada afición a lo sublime, lo tétrico y lo extravagante, y eso sin perdonar al popularísimo Isaacs, en cuya novela Maria (I867) hallaba un sentimentalismo empalagoso, que echa a perder el sano costumbrismo que la hace tan americana y tan nuestra. Sólo los clásicos del Siglo de Oro y los maestros del siglo xIx, sus afines, colmaban hasta cierto punto sus anhelos y le daban orientaciones: el Cervantes del Quijote y las Novelas ejemplares; el Fernando de Rojas de La Celestina; el Quevedo de los Sueños; el Alarcón de El sombrero de tres picos y las Histarietas nacionales; el Valera de Pepita Jiménez y El Comendador Mendoza); el Palacio Valdés de La Hermana San Sulpicio y José; el "Clarín" de La Regenta; el Coloma de Pequeñeces; la Pardo Bazán de los cuentos y de Los Pazos de 
Ulloa; el Blasco Ibáñez de Cañas y barro y La Barraca, y el Galdós de Fortunata y Jacinta y Misericordia. Los leía y estudiaba. Aprendía de ellos la técnica novelística, y en ellos hallaba inspiración para crear cuentos y novelas regionales, sin imitar a ninguno ni plagiarlo. Cultivaba y perfeccionaba su propio estilo, y escribía por necesidad de expresarse y comunicarse. Por invitación de sus amigos, en 1893 se dio a conocer del público antioqueño con el cuento "Simón el mago", y en 1896 , maduro ya y literariamente formado, editó en Bogotá la jugosa novela Frutos de mi tierra, escrita "cuando todavía no habia leído ni una línea de Pereda", el maestro santanderino con quien Cejador y Frauca llegó a compararlo, sin tener para ello muchas razones de verdadera validez.

Como lo apunta Federico de Onís, el nombre de Carrasquilla se hizo oír en España y en Colombia precisamente en los momentos en que decaían el romanticismo y el romanticismo en América, y triunfaba el modernismo amigo de lo exótico y lo artificioso, y poco inclinado a lo nativo y lo sencillo. Por eso el modernismo aisló y negó a Carrasquilla, pero él siguió produciendo, sin abandonar su orientación regionalista y depurando y avanzando su técnica, hasta convertirse en el precursor de nuestra novela moderna. Su actitud es explicable y ejemplar: él era un patriota para quien "recordar y comentar lo propio es vivir", un poeta para quien "la palabra es el alma de las personas", y un artista de su tierra - que no de su tiempo-, y como tal no gustaba de las modas que pasan sin dejar huella profunda en el alma colectiva de los pueblos que aspiran a la cultura sin renunciar a sus propios modos de ser y de sentir.

III

\footnotetext{
"Sin alma no hay arte posible".

"Para el poeta todo asunto es bello: la poesía está en el sujeto, que no en el objeto".

"No le basta a un artista expresarse bien: necesita expresarse tal cual es".
}

T. C.

Tomás Carrasquilla, precursor de la novela moderna, es quizás el único novelista hispanoamericano de su tiempo que tuvo conciencia plena de su arte y sus intenciones. Buen crítico de sí mismo y de sus obras, él profesó una estética firme y sencilla, clara expresión de su temperamento y reflejo fiel del medio ambiente en que se formó; una estética propia que, 
aun en sus lados débiles y negativos, se define frecuentemente en sus es. critos de crítica y polémica, y se realiza y logra casi siempre en sus cuentos y novelas, admirables modelos de sinceridad literaria y artística.

Carrasquilla, el hombre, ${ }_{2}$ sentía y vivía el ambiente antioqueño en sus múltiples aspectos y manifestaciones, pero a menudo buscaba la soledad; en que "el alma se encuentra, si se busca", y el campo, en cuyos aires flota a veces "un espíritu de santidad que difunde paz y alegría"; amaba la naturaleza, "más bella que el arte", y la sencillez, "que informa toda existencia" y "resume todas las virtudes"; confiaba en la razón que, "si domina al sentimiento, lo muestra en su grandeza", pero no renunciaba a la ilusión, que consuela al desgraciado y le da alas para elevarse a lo infinito; y si sufría el presente y tenía fe en el porvenir, prefería refugiarse en el pasado, idealizándolo, porque "en el Pasado el hombre se apacienta y arraiga".

Carrasquilla, el esteta, seguía los mismos rumbos que Carrasquilla, el hombre...

La estética del maestro antioqueño, en sus raíces, tiene puntos de contacto con la positivista de Taine y de Guyau, con la idealista de Platón, y con la subjetivista de los románticos alemanes. Aceptaba la definición de Taine, según la cual el arte es la naturaleza a través de un temperamento, y tenía, como Guyau, un alto concepto de su valor y su función social. "El arte — decía- es la ciencia en su forma más sintética y estable, y más trascendental, por ende, que la ciencia misma", pues "si las ciencias hacen feliz al hombre en sentido positivista y determinado, el arte le embellece la vida en su sentido abstracto y general, y la traslada a la región de la idea y de la belleza moral". No creía - como Platón-, que el fin del arte es encarnar el Bien moral, pero sí afirmaba que él "es el mejor maestro para enseñar al hombre la hermosura, la poesía y el significado de la vida, y el dolor inmenso que la vida misma trae consigo". Admiraba el arte griego por la sencillez, la sinceridad y la elegancia que lo caracterizan y distinguen, y lo hacen "dominante en el imperio de la belleza", y lo amaba -asi en la arquitectura, la escultura, la poesía y la oratoria-, porque ese arte, más que ninguno otro, le trae al alma de quien lo contempla el sentido de la gracia, la fuerza y la armonía, y "le sugiere lo divino y espiritual del hombre y de las cosas".

Individualista, a fuer de buen hispano, Carrasquilla era realista $c$ idealista al mismo tiempo: tenía fe y confianza en los principios absolutos y eternos; sostenía que el afán primordial del arte es crear belleza, y que la artística "no se va a los sentidos, sino al espíritu", y es su creación; creia que "todo está dentro de uno mismo", que "el mundo objetivo no 
es más que un reflejo del subjetivo", que "lo de afuera nos lo asimilamos y lo convertimos en nosotros mismos", y que, "si tal asimilación no existiese, todo nos fuera indiferente", y ninguno de nosotros podría convertirse en un yo capaz de expresarse de modo original y convincente. "Sin alma no hay arte posible" - decía-, y luego añadía: "Lo estético no es otra cosa que lo verdadero en lo bello", y la belleza es tan sólo "una facultad psíquica" personalísima, no del todo comunicable. Lo artístico no era para él representación directa de la realidad objetiva -la que está yacente fuera de nosotros-, ni tampoco la encarnación de la verdad cien. tífica, como le parecía a Aristóteles. El se inclinaba hacia los subjetivistas alemanes, y habría podido decir con el maestro Eckhart que la belleza es el amor, y que éste trueca al hombre en la cosa que éste ama con religiosa unción.

Para Carrasquilla - como para el platónico don Juan Valera, a quien en esto se parece-, "hay en cada uno de nosotros un criterio estético que precede a la representación de la naturaleza y aun a su observación", un ideal "que nos guía para reconocer la hermosura objetiva y reproducirla en nuestras obras". El arte no es mera representación, sino más bien "la manifestación de la idea que en el alma llevamos de ella, revistiéndola en forma sensible", cualesquiera que sean los medios de que nos valemos para tal empresa de creación.

Fiel a su credo estético - positivista, platónico y subjetivista al mismo tiempo-, Carrasquilla creó sus ficciones, realistas y poéticas. No ignoró nunca la realidad ambiente, y se documentó siempre de modo personal y directo, pero al crear combinó a menudo lo observado con lo imaginado, lo visto con lo presentido, y les dio una sutil y afortunada unidad estética que cautiva y deleita por su verismo y su difícil naturalidad. Sus cuentos y novelas son su propia alma proyectada en lo sensible -escenarios, episodios, personajes, etc.-, una creación asombrosa, ya por su "realismo", ya por su bien frenada elación ética y espiritual. ¿Son esas ficciones un engaño más "en este mundo de duelo y de aflicción?"... Sí, hasat cierto punto. Mas no nos quejemos de ello, que la vida es sueño: "del engaño vivimos todos", y "todos tenemos la propensión a creer en el espejismo de nuestras propias ilusiones" y nos atenemos a la fantasía, "que dispone de mil recursos y sortilegios y embrujamientos" para hacernos llevaderas la vida y sus miserias cuotidianas.

Hombre medio estoico y esteta muy consciente, Carrasquilla fue también un poeta de inclinaciones románticas, discretas y reminiscentes, como bien lo atestiguan sus cuadros, cuentos y novelas. 


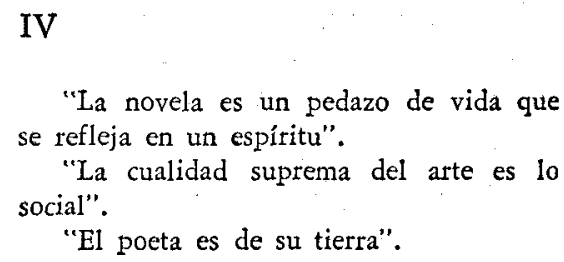

T. C.

Tomás Carrasquilla fue un escritor variado y fecundo. En sus Obras completas (Editorial Bedout, de Medellín) figuran varios ensayos y estudios de crítica y polémica, muchas crónicas, cuadros, acuarelas, "dominicales" y epístolas, que constituyen una labor interesante para quien desea conocer su ideología, su intimidad de hombre, su actitud ante las diversas corrientes literarias de la época, y su apego a la tierra de sus mayores. Figuran también en ellas diez y seis cuentos y once novelas más o menos largas y de méritos desiguales, que encierran lo más original y valioso de su quehacer artístico.

En los cuentos y novelas, Carrasquilla nos revela su amor a la verdad y la sencillez, y su lealtad a la tierra en que vivió, y a sus gentes y modos de ser, sentir y obrar, a sus tradiciones, creencias y virtudes, y aun a sus vicios y supersticiones. Es natural. Para él la novela era, no sólo un pedazo de vida que se refleja en un espíritu, sino "la manifestación suprema de la mente humana", porque ella "implica ciencia y sentimiento", al recoger "así el hecho histórico como el imaginado", y porque en ella "se confunden todas las escuelas" y a ella "convergen todas las tendencias", con excepción de las que señalan mentiras y simulaciones.

Fiel a sus ideas y a su regionalismo invulnerable, Carrasquilla hacía uso de todo en sus ficciones, y todo lo conjugaba sabiamente para dar la nota insuperada de un antioqueñismo un tanto limitado pero humano, profundamente humano y universal. Todo: escenario, episodios, ideas, sentimientos y sensaciones, y por encima de ello, el lenguaje en que se expresan así el autor como sus muy castizos personajes.

Imagen verdadera y precisa de la vida y del ambiente antioqueños, la novela de Carrasquilla es cotidiana, recia, uniforme y pintoresca como aquélla, y como éste sorpresiva y llena de accidentes. No es novela de tesis: no se propone enseñar ni probar ninguna doctrina, ni profesar teoría alguna. Su escenario - con la sola excepción del cuento intitulado "El rifle"- es el antioqueño, y su trama es tan sólo la necesaria para que los personajes y los conflictos se nos presenten y nos hagan sonreír o sus- 
pirar, según el caso. Es una novela de caracteres, a menudo escrita en forma autobiográfica y dialogada.

Carrasquilla no le daba a la trama novelística la importancia que otros le han dado, y que tanto buscan algunos lectores, entre ellos los anglosajones. Al contrario: para él "la poca trama es una de las cualidades principales de la novela, pues si ella ha de reflejar la vida, debe hacerlo tal cual es: sin mayores complicaciones, con la monotonía de los sucesos ordinarios, con las insignificancias cuotidianas", para así parecer "más humana" y convincente. Le daba, sí, grande importancia al tono en que se escribe una novela, y aplaudía a los artistas que logran "reproducir con la pluma escenas y episodios comunes", pergeñar un volumen "con hechos vulgares" y presentarlos "sin incurrir en sublimidades ni chabacanerías impertinentes".

Aspirando a la serenidad de los clásicos, Carrasquilla utilizaba en sus ficciones sólo los temas sencillos y despejados, y si evitaba las tramas complejas y bien estructuradas - porque le parecían artificiosas y contrarias a la realidad vital-, en cambio, concentraba la atención en el estudio y la pintura de los personajes y del medio ambiente en que se mueven y viven. Los estudiaba con escrúpulos de científico concienzudo, y los describía y pintaba con esmero y simpatía de artista leal y justiciero, sorprendiendo siempre en ellos lo esencial y permanente.

Carrasquilla hallaba los personajes de cuentos y novelas entre los campesinos, los aldeanos y las clases medias de la ciudad, por creer que todos ellos, más que las gentes alta y civilizadas, encarnan de veras el alma colectiva de un pueblo, no inficionada de extranjerismos y libre de modas pasajeras. Pero sabiendo que "en la vida, por ley de armonía... hay superiores e inferiores, directores y dirigidos, envidiados y envidiosos", a todos los captaba, los mezclaba en sus novelas, y los retrataba sin prejuicios, logrando contrastes pintorescos, eficaces y entretenidos, dentro del buscado equilibrio novelesco. Se complacía en la pintura de niños y mujetes, en la del pueblo humilde, y en la de "las ruinas humanas", no porque fuese triste y pesimista, sino porque las hallaba "fecundas" y dignas de simpatía, por "implicar dolores, humillaciones y desengaños" de sumo interés para el psicólogo y para el artista que persigue altos fines morales y estéticos.

Muy numerosos y variados son los personajes de Carrasquilla. Por sus cuentos y novelas desfilan varios cientos: campesinos astutos y honradotes; mineros fuertes y jacarandosos; arrieros estoicos y vivarachos; criados entrometidos y fieles; artesanos sufridos y laboriosos; usureros codiciosos y sórdidos; aventureros egoistas y bellacos; sacerdotes caritativos y cu- 
ras partandistas; beatas chismosas y mojigatas halaraquientas; mozas del partido, fregonas y alcahuetas, "brujas" muy "vivas" y engañosas; gamonales arbitratios y políticos de pacotilla; tinterillos y buscapleitos voraces y enredadores; médicos y yerbateros; "damas" deslumbradas por el fulgor de la grandeza; damiselas regalonas y tontas, enamoradas del "buen tono" y el "brillo" social; niñas halucinadas, de "místicas" inclinaciones, y adolescentes que simulan santidad; arrivistas y oportunistas sin escrúpulos; caballeretes de pega y apariencia; señorones de tuerca y zancadilla, etc., etc., y también algunos señores de verdad, y señoras decentes, honorables y discretas: todo un pueblo en fermento, en su vida dinámica y democrática, y en sus aventuras y vicisitudes, ora cómicas, ora trágicas: el pueblo antioqueño del siglo pasado, un pueblo que "se iba", al modernizarse, y que, no obstante, seguía y sigue siendo el mismo en sus virtudes y sus vicios...

Entre tantos personajes carrasquillescos, ninguno es en verdad sobresaliente, aunque algunos son muy impresionantes. Ninguno es de tipo heroico, como un don Quijote, un don Juan, un Hamlet, un Brand..., porque ninguno encarna un símbolo supremo. Ninguno tiene conciencia plena de las fuerzas económicas, políticas y espirituales que operan en la sociedad humana: todos son individuos más o menos ordinarios, seres cuya tragedia, o comedia, tiene un desenlace de poco interés y poca monta para los destinos de la sociedad en que se agitan. Todos son tipos corrientes, pero Carrasquilla los pinta, asi en lo físico como en lo moral, con tal verismo y simpatía, con tanta sobriedad y precisión, y con tal afán de revelar lo que, aun en los más bajos, hay de noble y de humano, que todos impresionan al lector y le hacen pensar que se halla en compañía de sus conocidos y allegados.

La de Carrasquilla no es novela psicológica, en el sentido que ahora se le da a tal denominación: sus personajes carecen por lo común de verdadero desarrollo interno: son casi todos asi, tal y como aparecen en la novela, en un momento dado, para luego desaparecer, sin haber sufrido cambios esenciales. Son personajes que, como los de la vida real, vienen y van, sin mostrársenos en su totalidad, ni mucho menos en su desenvolvimiento temporal, y todos se revelan, más que por sus acciones, por el lenguaje que usan en sus quehaceres, sus afanes y sus tribulaciones del momento. Todos obran, es cierto, pero más que todo, hablan: su habla, en sus variados aspectos, es el medio característico de expresión.

¡El habla!... Cuán importante es en la novela de Carrasquilla, y cuán poco apreciada es por los lectores apresurados y los inexpertos. Unos la creen libresca y "copiada". Otros la estiman "incorrecta", vulgar e insoportable, y pocos la aprecian en todo su valor... 
Si el escenario y los personajes de la novela carrasquillesca son convincentes, por lo plástico y verídico, mucho más lo son por el lenguaje que los pinta y caracteriza. Por él se distingue nuestro autor entre sus contemporáneos, y por él sus novelas tienen una originalidad y un encanto peculiares e inusitados.

Carrasquilla se familiarizó con la Gramática y la Preceptiva, "que enseñan a expresarse", pero desconfiaba de su eficacia, porque "no enseñan a pensar ni a sentir"; conoció a fondo a los grandes hablistas de allende y aquende el mar, desde el español Juan de Valdés hasta el antioqueño Marco Fidel Suárez, pero desconfió de los estilos impecables y pulidos, por hallarlos más propios del ensayo que de la novela, y se burló donosamente de ciertos escritores "archi-académicos", que "poco dicen" en su relamida latiniparla pedantesca. Conocia a los grandes hablistas, pero no los imitaba ni se dejaba subyugar por la magia de su estilo. Sabía que hablar es fabu$l a r$, es crear, y que imitar un estilo vale tanto como "imitar un temperamento" y asumir una actitud simiesca, ridícula e imperdonable.

Carrasquilla decía que "la palabra es el verbo, el alma de las personas"; predicaba la necesidad de ser uno fiel a sí mismo y a su tierra, y de expresarse "tal cual es", sin "adornarse" inútilmente. Lo predicaba y lo practicaba. Escribía como hablaba, y hablaba como se habla en Antioquia, en Santander, en el Cauca y en otras regiones de Colombia; como se habla en varias comarcas de Méjico y Centroamérica, del Perú, de Venezuela, de Chile y la Argentina; como se habla en Asturias y otras provincias de España: como se babla en dondequiera que el idioma castellano se ba conservado en su mayor pureza y lozania, y en su casticismo secular.

Sostenían algunos puristas que el lenguaje popular antioqueño era rústico, incorrecto, áspero y feo, y que por lo tanto no debía tener cabida en la novela. Carrasquilla "se atrevía" a sostener lo contrario. "Pocos habrá - decía - tan gráficos, tan expresivos, tan pintorescos, como el lenguaje de nuestro pueblo. Ese lenguaje, esmaltado de imágenes, de frases hechas, riquísimo en léxico, en voces viejas que sólo usan los clásicos, lo consideramos lo suficientemente bello para verterlo en un libro, sin mayores componendas". Lo sostenía, y con entera libertad y gran maestría usaba ese lenguaje en sus cuentos y novelas, sin sacarlo de autores extranjeros y sí de la entraña misma del pueblo. ¿Y por qué no? "Si la naturaleza es más bella que el arte"; "si el artista, en su empeño de reproducir lo bello y lo verdadero, no tuvo siempre en cuenta la moral. . . ni a veces la decencia tan siquiera, ¿por qué razón... va a ser más respetuoso con la gramática" y el "buen gusto" ?... ¿Por qué no utilizar discretamente del habla popular, que "no puede tener sintaxis", por ser ésta "privativa del lenguaje 
culto, del lenguaje escrito"? Y si "no siempre los académicos de la lengua hablan y se producen en la vida real con el mismo atildamiento y la mismapropiedad con que escriben", ¿por qué desterrar de la novela el lenguaje popular, si la moderna aspira a revelar y pintar el ser mismo del pueblo, que lo usa sin escrúpulos ni miramientos, y lo va creando sin cesar?

Siguiendo el buen ejemplo de los clásicos de la novela española, Carrasquilla, en los diálogos en que la suya abunda, utilizó el habla de los campesinos, los aldeanos y las gentes de medio pelo, sus personajes favoritos. ¿Y cómo no? "Siendo la palabra lo que mejor da a conocer al individuo y a la sociedad... no debe cambiarse esta palabra por ninguna otta más correcta ni más elegante, porque entonces le quita a los personajes pintados la nota más precisa, más genuina de su personalidad". Por eso, "cuando se trata de reflejar en una novela el carácter, la índole de un pueblo o de una región determinada, el diálogo escrito debe ajustarse rigurosamente al diálogo hablado, reproducirlo hasta donde sea posible", sin falsearlo nunca, y no sólo en los giros y palabras, en las imágenes y modos de expresión, sino hasta en su fonética, "para ganar en colorido y fidelidad", y aunque se corra el peligro de la incorrección y aun en el de la chabacanería. Así lo hicieron Fernando de Rojas, en la Celestina, Cervantes en el Quijote y en algunas novelas ejemplares, el Arcipreste de Talavera en $\mathrm{El} \mathrm{Corvacho,} \mathrm{y} \mathrm{todos} \mathrm{los} \mathrm{autores} \mathrm{picarescos.} \mathrm{Así} \mathrm{lo} \mathrm{hicieron} \mathrm{Palacio}$ Valdés y Blasco Ibáñez, aquél en José y La Hermana San Sulpicio y éste en La Barraca y en Cañas y barro, y así lo hizo Pereda en Escenas montañesas, en Sotileza y en los demás cuentos y novelas de la "tierruca", aunque no con tanta fidelidad como aquéllos. El diálogo en Pereda es bello y gracioso, pero también "artificioso y engalanado", y un tanto libresco. Ese diálogo - como lo apuntó el mismo Carrasquilla y puede comprobarlo quien lo intente- "fuera de la anteposición del artículo definido a los posesivos; fuera de las terminaciones femeninas en "uca", de algunas voces corrompidas y de ciertas contracciones peculiares del lenguaje santanderino, todo lo demás, toda la estructura, resultan de una sintaxis rigurosa, de un giro casi cervantino. No hay más sino hacer la substitución de las palabras correctas por las adulteradas para persuadirse de ello".

El maestro antioqueño no cayó en tan señoril superchería. Êl fue siempre fiel al hablar del pueblo, a ese continuo fabular, siempre viejo y siempre nuevo, libre, desenfadado y atrevido, y rico en los jugos de la tierra, de la vida y del espíritu. En esto, y muy a conciencia, fue más lejos que Palacio Valdés, que Blasco Ibáñez y que el mismísimo Pereda: Carrasquilla -como bien lo dice Federico de Onís- asimiló por completo el habla del pueblo, la convirtió en sustancia propia, la elevó a categoría 
literaria, y en ella se expresó con suma independencia, logrando crearse un estilo muy suyo, llano, sencillo, copioso, animado, y medio rancio y nutritivo como los quesos añosos y selectos; un cstilo elástico y variado, recio y enérgico en ocasiones, y en otras suave y apacible; un estilo de riquísimo léxico e imágenes naturales y precisas, abundante en innovaciones verbales que cautivan y nunca chocan, por no ser caprichosas, ni amaneradas ni arbitrarias; un estilo que a veces se resuelve en humorismo, y otras se unge de esa poesia noble y discreta que inspiran la naturaleza, el pueblo y sus costumbres.

Algunos cuentos y novelas de Carrasquilla, elaborados con sus propias experiencias, tienen forma autobiográfica, conversacional y dialogada. Esta forma - conocida desde los tiempos de la picaresca-, adquiere en él nuevos y aquilatados aspectos, y le permitió identificarse totalmente con sus personajes y el medio ambiente, $\mathrm{y}$ usar el lenguaje del pueblo no sólo en los diálogos, sino en los relatos y las descripciones. Tal sucede, por ejemplo, en la trilogía Hace tiempos, y más en el cuento intitulado "En la diestra de Dios padre", obra maestra si las hay en castellano en un género tan difícil y exigente: el del cuento vernacular que expresa en síntesis el alma misma, no ya del autor, sino del pueblo.

Mucho se ha discutido el habla de Carrasquilla, utilizada en sus novelas. Algunos han creído ver en ella una jerga ininteligible, indigna de "personas bien educadas", abusivamente regional. Otros, con razones de mayor validez científica, la han defendido y explicado. Otros la han saboreado y apreciado. Unamuno llegó a decir que esa habla no era regionalista, sino "castellano viejo", ya desusado por las gentes cultas, ya de España, ya de América. Cejador y Frauca consideró su lectura "provechosísima para aprender el castellano verdadero, que es el verdaderamente popular" en el mundo hispánico, y Sanín Cano, sin terciar en el asunto, concluyó: "la verdad es que las brillantes y portentosas cualidades de escritor y poderoso y gracioso estilista, en el sentido crítico más puro de este calificativo, no puede apreciarlas quien no conozca en todas sus variedades y matices el decir antioqueño", que tan bien se despliega y juguetea en Carrasquilla, y más en sus cuentos y novelas que en los escritos en que usa el lenguaje corriente de las gentes cultas. Así será, y sin embargo...

Es cierto que en Carrasquilla hallará el lector muchos arcaísmos y americanismos, muchas contracciones, algunos negrismos, $\mathrm{y}$ aun uno que otro extranjerismo. ¿Es esto peculiar y exclusivo del decir antioqueño y carrasquillesco? Convendría estudiar el punto, a la luz de la lingüística moderna. Yo de mí sé decir que, salvo algunas contracciones y algunos negrismos, nada he hallado en Carrasquilla que yo no hubiese oído de niño 
y de adolescente, allá en mi provincia natal de García Rovira, situada en el oriente del Departamento de Santander, lejos de Antioquia y poco visitada por sus gentes. Lo mismo dirán otros lectores de otras regiones de América y de España. El castellano de Carrasquilla es muy puro y castizo, y bien lo entienden los lectores de habla castellana, aunque a veces no perciban todos los matices del decir antioqueño, como no perciben todos los del decir argentino, el venezolano, el asturiano, el mejicano... La culpa no es del escritor, sino del lector, por una parte, y por otra, de las Academias que no siempre recogen en sus diccionarios las palabras y paremias que el pueblo va creando unas veces por necesidad de los tiempos y lugares, ora por la no menos vital de crear y de expresar... No hay en Carrasquilla ni giros ni vocablos que no estén formados según las leyes y el genio de la lengua castellana. Quien no los entienda y aprecie en todo su valor linguístico y estético, debe estudiarlos, ampliando así su conocimiento de la lengua y mejorando su capacidad para saborear sus infinitos encantos y matices...

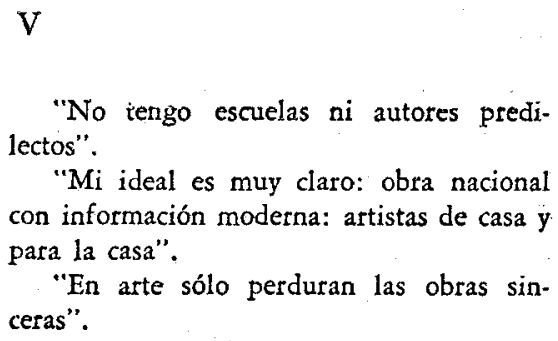

"No rengo escuelas ni autores predi-

"Mi ideal es muy claro: obra nacional con información moderna: artistas de casa y para la casa".

"En arte sólo perduran las obras sinceras".

T. C.

Tomás Carrasquilla - repito, haciéndole eco ai juicio de Federico de Onís-es el precursor de la novela hispanoamericana moderna, y uno de los novelistas más interesantes del Continente, aunque así no lo reconozca todavía la crítica provinciana, tan ciega y llena de prejuicios. En sus cuentos y novelas se nota siempre su amor a la verdad, la sencillez y la belleza humilde y cotidiana; su memoria prodigiosa y su gran poder de observación; su capacidad para sacar partido de cualquier cosa y hacer algo de cualquier nonada; sus muchos conocimientos de la psicología de niños y mujeres; su interés en los caracteres dominados por una idea fija, que los conduce generalmente al fracaso y la tragedia; su habilidad para hallar lo grande en lo pequeño, lo permanente en lo pasajero, y lo universal en lo 
que parece puramente local; su honda y firme lealtad a su tierra, y por encima de todo ello, su extraordinario dominio del lenguaje vernacular.

Ningún estudioso de la novela hispanoamericana se anima hoy a negarle importancia a Carrasquilla, y ninguno hay que no vea en él "un escritor de valor único e insustituible en nuestra literatura", un novelista de primer orden, cuya obra "tiene todas las trazas de llegar a ser clásica e imperecedera".

Carrasquilla fue un precursor y un maestro. En casi todo se les anticipó a sus contemporáneos, y aquí y allá dejó discípulos que conocen sus huellas y las siguen.

Carrasquilla reaccionó contra el costumbrismo, por lo superficial y rastrero, y lo superó, elevando sus temas, dándoles profundidad y transformándolos en obras de positivo valor estético; rechazó los aspectos sensibleros, declamatorios y falsos del romanticismo, conservando de éste sólo el amor de la naturaleza y el respeto al sentimiento verdadero y legítimo; reaccionó contra los elementos sombríos y fatalistas del naturalismo-que no contra algunos de sus procedimientos técnicos-, y proclamó su fe en el libre albedrío y la dignidad del hombre y la del individuo; reaccionó contra el decadentismo y el simbolismo, por lo enfermizo y simulado aquél, y éste por lo vago, lo exótico y lo hermético, y defendió la salud física y moral, el orden, la sinceridad y la precisión científica, y predicó la conveniencia de un arte nativo, claro y comunicable, un arte del hombre y para la sociedad, que no para los grupos de "iniciados" ni de "admiradores" incomprensivos y adulones. Reaccionando contra las escuelas y tendencias de su tiempo, foráneas todas, él halló inspiración en el medio ambiente americano, y sin dejar de ser tal cual era, pudo volver fácilmente al arte hispánico, variado y armonioso, realista e idealista a la vez, y siempre vigoroso y popular en sus manifestaciones más castizas y originales.

Como todo tradicionalista, Carrasquilla tuvo sus prosélitos, y como todo precursor, "mereció" la inquina de los jóvenes partidarios del arte "refinado" y cosmopolita tan en boga en nuestra América. Ellos lo negaton, lo aislaron y lo vapularon, pero él sigue su firme carrera hacia lo porvenir...

Carrasquilla se acercó a los maestros de la novela francesa, la inglesa y la rusa del siglo xix -Balzac, Flaubert, Dickens, Thackeray, Tolstoy, Dostoievsky, etc.-; se familiarizó con los maestros españoles de todos los tiempos, desde los clásicos hasta los modernos; se sintió atraído por Cer. vantes, Galdós, la Pardo Bazán y Blasco Ibáñez, y también por Unamuno y por Baroja, pero no imitó a ninguno de ellos, ni menos a Pereda, como lo suponen algunos críticos. Carrasquilla fue muy independiente, y si hạ- 
lló inspiración en la lectura y recogió del pueblo algunos cuentos y consejas, fue original siempre y siempre él mismo. Su arte es clásico a la manera hispánica: prefirió el humor y la pintura de tipos y costumbres al análisis minucioso de la novela francesa; no le dio importancia al enredo y a la estructura arquitectónica, que tanto distingue la novela inglesa, y no se dejó deslumbrar ni por la angustia ni por el pesimismo que anima a la rusa. Fue hispánico, y como tal, produjo algunas obras que bien pueden figurar entre las mejores que en tiempos modernos se han escrito en castellano.

Es cierto que Carrasquilla no cuenta entre los suyos un cuento tan vivo, regocijado y chispeante como El sombrero de tres picos (1874), de Alarcón, ni entre sus novelas una tan soleada como Pepita Jiménez (I874), ni tan rica como El Comendador Mendoza (1877), de Valera; ni una tan movida y graciosa como La Hermana San Sulpicio (I889), de Palacio Valdés; ni una de tan vastas perspectivas y vivencias como Fortunata $y$ Jacinta (1 886-87), de Galdós, o como Peñas arriba (I895), de Pereda; pero sí cuenta varias tan convincentes como La Regenta, de "Clarín", Los Pazos de Ulloa, de la Pardo Bazán, y La Barraca, de Blasco Ibáñez. Como estilista, Carrasquilla no igualó la plasticidad de Alarcón, ni el primor y la elegancia de Valera, ni la claridad de Palacio Valdés, ni la asombrosa variedad de Galdós, ni la grandiosidad de Pereda en las descripciones de la naturaleza, pero sí aventajó a la Pardo Bazán y a Blasco Ibáñez por la sobriedad y la precisión.

Por sus creaciones, recias y logradas, Carrasquilla debe figurar entre los maestros que enaltecen y glorifican nuestra producción novelistica, más optimista que la rusa, y más original y vigorosa que la francesa y que la inglesa, aunque no tan acabada y brillante como aquélla, ni siempre tan profunda y elevada como ésta.

Entre los cuentos de Carrasquilla sobresalen "En la diestra de Dios padre", "Dimitas Arias", "San Antoñito", "El rifle", "Salve Regina" - su favorito-, y otros, y entre sus novelas: Frutos de mi tierra, sobria y jugosa; Entrañas de niño y Ligia Cruz, muy delicadas y sentidas; Grandeza, la única que nos presenta la vida de las "clases altas" de la vieja capital antioqueña; El Zarco, cuidadosamente elaborada; Por aguas y pedrejones primera de la trilogía Hace tiempos; y La Marquesa de Yolombó, la de mayor aliento y la mejor estructurada de todas, en que Carrasquilla intentó la reconstrucción de la vida antioqueña de fines del siglo xvir y principios del XIX.

Ninguno de los cuentos y novelas de Carrasquilla anteriores a 1920 -ęs dẹcir cași todos-, tenía ạtẹcedentes en la novelística hispanoameri. 
cana, asentada entonces, ora en el costumbrismo "ameno", dislocado y decorativo, ora en el romanticismo azucarado y sentimental, ora en el moder-. nismo desarraigado del ambiente americano, como bien se ve en Manueld; de Eugenio Díaz y en Martín Rivas, de Blest Gana; en Maria, de Isaacs, Cumandá, de León Mera y La Navidad en las montañas, de Altamirano, y en La gloria de don Ramiro, de Larreta, por citar sólo unas pocas entre las más célebres del Continente. Con las suyas inició Carrasquilla entre nosotros el criollismo auténtico, al entrar de lleno y en firme en la entraña misma del pueblo y del ambiente americanos, y al utilizar el lenguaje popular como medio único y válido del quehacer novelístico autóctono $\mathrm{y}$ sincero. Sólo después de esos cuentos y novelas de Carrasquilla vinieron en Hispanoamérica, Los de abajo y La luciérnaga, de Azuela; La Vorágine, de Rivera; El romance de un gaucho y El inglés de los güesos, de Lynch; Juan Criollo, de Loveira; Doña Bárbara y Cantaclaro, de Gallegos; Don Segundo Sombra, de Güiraldes; El mundo es ancho y ageno, de Alegría, y el Huasipungo de Icaza, "novela de la gleba en que la lengua vernacular deja de ser castellano", para convertirse en jerga inintelegible para quienes no conocen el idioma quechua de los indios y cholos ecuatorianos.

En Antioquia, donde ha laborado un grupo interesante de novelistas, le siguieron los pasos al maestro Carrasquilla: su íntimo amigo, don Francisco de Paula Rendón, con su bella novela Inocencia; Francisco Gómez ("Efe Gómez"), con sus cuentos; Eduardo Zuleta, con Tierra virgen; Samuel Velásquez, con Madre, muy delicada y artística, y algunos más. En Venezuela los siguió también Teresa de la Parra con Las Memorias de Mamá Blanca, en que se oyen ecos de Carrasquilla. Otros los habrán de seguir en todo el Continente, cuando sea más conocida y apreciada la obra, clásica y moderna, de este antioqueño señero, consciente y americanista.

Carrasquilla no es un escritor "reaccionario", "ultramontano" y meramente "regionalista", como lo sostienen quienes lo discuten de oídas, sin familiarizarse con sus obras. No es tampoco "el Pereda colombiano" -que dicen los amigos académicos, juzgándolo sólo por algunas semejanzas de temperamento y de ideología, y por ciertos aspectos adjetivos de la técnica literaria. En realidad - como bien lo señala Onís-Carrasquilla se parece más a Galdós que a Pereda, y como novelista, más parentesco tiene con Blasco Ibáñez, por una parte, y por otra con Baroja, Unamuno y Valle Inclán, que con el admirable maestro santanderino. Carrasquilla pertenece al movimiento modernista en lo que tiene de esencial: es subjetivo, a pesar de su aparente realismo "objetivista" e impasible... Era un poeta romántico y reminiscente: el poeta de Antioquia, la región colombiana que produjo ayer a Gregorio Gutiérrẹz González, y después a Porfirio Barba Ja- 
cob y a León de Greiff, grandes poetas, más famosos quizá que el hijo de Santodomingo, aunque ninguno de ellos llegó a crear la epopeya antioqueña que sí dejó él en sus cuentos y novelas.

La obra artística de Carrasquilla es a Antioquia, y por ende a Colombia, lo que el Cantar de Mio Cid es a Castilla, lo que el Martín Fierro es a la Argentina, aunque no está escrita en verso, sino en prosa muy castiza y personalísima: es una obra augural, la expresión del pueblo antioqueño, llamado, como el castellano y el argentino, a muy altos destinos históricos... Esa obra ha calado ya muy hondo en el alma del pueblo, y le da vivencias, normas y orientaciones. Y seguirá calando. Por eso es clásica e inmortal.

\author{
Carlos García Prada, \\ Olga, Washington, E. U.
}

